\title{
Types of listening comprehension promoted in the Chilean EFL textbook Global English
}

\section{Tipos de comprensión auditiva desarrollados en el texto chileno para inglés como lengua extranjera: Inglés Global}

Benjamín Cárcamo Morales ${ }^{1}$

Citation/ Para citar este Artículo: Cárcamo, B. (2018). Types of listening comprehension promoted in the Chilean EFL textbook Global English. Colomb. appl. linguist. j., 20(1), pp. 49-61.

Received: 16-Jul.-2017 / Accepted: 19-Oct.-2017

DOI: https://doi.org/10.14483/22487085.12313

\begin{abstract}
This article reports the results and reflections of an analysis of the EFL textbook provided by the Ministry of Education of Chile to all $11^{\text {th }}$ graders in public and subsidized schools. The objective of this article is to identify the type(s) of comprehension developed in the listening comprehension section. In order to achieve this, a descriptive quantitative study was carried out which consisted of the design and application of a checklist developed based on Day and Park's (2005) taxonomy. Four different experts analyzed the textbook reaching $92.3 \%$ of agreement. The results show that the there is no clear progress across the units and that the vast majority of the tasks aim at comprehension at the surface level. This indicates a superficial treatment of listening in the textbook, which reduces the opportunities to develop it in depth.
\end{abstract}

Keywords: comprehension taxonomy, listening comprehension, textbook analysis

\section{Resumen}

Este artículo reporta los resultados y reflexiones de un análisis del libro provisto por el Ministerio de Educación de Chile a todos los niveles de 3ro medio en escuelas públicas y subvencionadas del país. El objetivo de este artículo es identificar los tipos de comprensión desarrolla en la sección de comprensión auditiva. En línea con el objetivo, se llevó a cabo un estudio descriptivo cuantitativo, el cual consistió en el diseño y aplicación de un instrumento que permitiese clasificar las actividades de comprensión auditiva según el tipo de comprensión que desarrollaban según la taxonomía de Day y Park (2005). Cuatro expertos aplicaron el instrumento alcanzando un 92,3\% de acuerdo. Los resultados muestran que no hay un progreso claro a lo largo del libro, lo cual reduce significativamente las oportunidades de incrementar la percepción de la comprensión auditiva como una habilidad activa y desarrollar la comprensión en profundidad.

Palabras clave: análisis de texto escolar, comprensión auditiva, taxonomía para la comprensión

1 Pontificia Universidad Católica de Valparaiso, Chile. benjamincarcamo.m@gmail.com 


\section{Introduction}

People spend most of their waking hours engaged in some form of communication. Listening, in particular, is the skill one spends most of the time using. In fact, about $50 \%$ of the time is spent on decoding and processing auditory input (Gilakjani \& Ahmadi, 2011). Likewise, language learners nowadays are much more exposed to this type of input in the form of songs on Spotify or videos on YouTube, among many others (Vandergrift, 2007). Although EFL learners may not have many opportunities to speak, read, or write in English, they seem to have more chances to put their listening skills to use. This increases students' interest in the skill, the responsibility that teachers have with developing it appropriately, and the attention researchers pay to the nature of this skill.

Research on listening comprehension has focused on varied aspects, such as affective factors (Gilakjani E Ahmadi, 2011; Lili, 2015; Xu, 2011) strategy use (Moradi, 2013; Vandergrift, 2004), sub-skills (Brown \& Abeywickrama, 2010) and the use of ICTs (Cárdenas-Claros $\varepsilon$ Gruba, 2014; Gruba, 2006). The results of this and similar research have changed the traditional view of listening comprehension. Within the traditional perspective, listening would be perceived as a passive, receptive Skill developed through listenand-repeat methods. Currently, methodologists suggest activities that involve bottom-up and topdown processes that highlight the active nature of listening comprehension (Lynch, 2009; Rost, 2011; Rost $\mathcal{E}$ Wilson, 2013). Following this trend, teachers may implement communicative tasks, in which reallife situations are simulated (Vandergrift, 2004).

This shift should prompt teachers to help students to interact with texts and construct meaning actively, so that they can develop higher-order thinking skills, such as critical thinking (Aloqaili, 2012; Echeverri E McNulty, 2010; Hosseini, Khodaei, Sarfallah, E Dolatabadi, 2012). To accomplish this, teachers are supposed to either design activities that aim at this goal or use textbooks that contain effective tasks, that is, tasks that stimulate students to make inferences, assess information, and express their opinions rather than just decode a text at a surface level.
Unfortunately, in Chile the methodologies and materials that teachers have been using do not seem to be achieving the expected results. Since 2010, Chile has incorporated into their national standardized tests the English SIMCE (MINEDUC, 2012). Two internationally validated instruments have been used at different times as the English SIMCE: the TOEIC Bridge test and, later, the KET exam. Through these instruments, the Ministry of Education has assessed the reading and listening comprehension skills of Chilean students in $11^{\text {th }}$ grade across the country. The results reveal that public and subsidized schools score significantly lower than private schools (Agencia de Calidad de la Educación, 2013, 2015). Consequently, it becomes important to identify factors that may be hindering the development of these skills in publicly funded schools within the country. One of these factors is the textbook used by the teachers.

Currently, the prospering market for textbooks has helped teachers count with many options from which to pick the most suitable material to use in their classes. However, in Chile, the government provides publicly funded schools with particular textbooks. In light of this, it is important to evaluate the quality of the textbooks that are being provided to teachers and used to develop most students' linguistic skills. Additionally, studying how these textbooks help students improve their listening comprehension is particularly important considering the studies that have shown that listening plays a crucial role in the development of other skills (Rost, 2011; Vandergrift, 2007) and the low scores public and subsidized schools get in the SIMCE (Agencia de Calidad de la Educación, 2013, 2015).

The present article has the objective of identifying the types of comprehension developed in the listening tasks in the EFL textbook provided by the Ministry of Education to $11^{\text {th }}$ graders in publicly funded schools. The organization of this article is the following: First, the article presents models of listening comprehension and Day and Park's proposal of types of comprehension. Then, the paper accounts for the methodology used to carry out the research. Next, the results of the investigation are presented and discussed. Finally, conclusions regarding the study and the role of EFL 
textbooks in developing listening comprehension are shared.

\section{Literature review}

\section{Listening Comprehension: Information Processing}

Listening comprehension has been approached in different ways depending on the pedagogical approach employed by the teacher. For example, under the audiolingual method teachers would use repetitive drills to increase students' understanding of formulaic expressions based on the patterns and grammatical structures the teacher was focusing on (Harmer, 2007). On the contrary, a teacher following the principles of communicative language teaching (CLT) will be interested in encouraging students to listen for meaning while either interacting with a classmate or listening to a recording (Flowerdew $\varepsilon$ Miller, 2005). One way of prompting students to interact with the recording in a meaningful way is through comprehension questions, which may lead to further discussions. In other words, questions that move the listeners from psycholinguistic to psychological concerns (Lund, 1990). In connection with this idea, comprehension questions have gained relevance since they allow teachers to focus on meaning-making and promoting high-order cognitive skills related to inference and criticalthinking (Danaye, Tahriri, \& Haghighi, 2015; Fahim, Barjesteh, \& Vaseghi, 2012).

In order to explain how a hearer can go from perceiving and recognizing sounds to understanding, analyzing, and commenting on information, researchers have proposed different models. Edwards (2007) presents an example of one of these models. The author explains that listening occurs in the interaction of two separate but connected levels: auditory periphery and cognitive levels. This bottom-up model acknowledges the importance of not only transducing linguistics signals, but also making connections between the information heard and other factors, such as contextual clues and linguistic information already stored in the brain in order to react accordingly to the input. Consequently, there would be four stages in this process: 1) hearing (transducing acoustic signals to physiological information); 2) listening (selecting information consciously); 3) comprehending (interpreting contextual, grammatical, and linguistic information); and 4) reacting (storing, reasoning, and responding). This last phase clearly emphasizes the interactive nature of the whole process and the active role of the listener when processing the input.

Geranpayeh and Taylor (2013) present a more complex model which has been used as theoretical support for the creation of Cambridge exams. This model identifies in a manner similar to Edwards' (2007), two different levels of processing: lower-level processes and higher-level processes. The former includes the phonological, lexical, and syntactic knowledge which account for the processing that occurs from input decoding to syntactic parsing. The latter involves the pragmatic and external knowledge, which allow the hearer to recognize intentions, monitor input processing, and build discourse representation among others.

Clearly, both models of listening comprehension go well beyond superficial understanding of information. Edwards (2007) explicitly states the importance of considering reacting to information as part of the processing of auditory input. To do this, going beyond surface level understanding is indeed fundamental. Moreover, the need for overcoming surface level understanding is noticeable in Geranpayeh and Taylor's (2013) proposal as they mention the need for understanding listening as the development of not only basic decoding skills, but also higher-level processes. Therefore, helping students develop their listening comprehension skill entails fostering processing that involves higherorder cognitive skills.

\section{From Listening Comprehension to Types of Comprehension}

Comprehension can be defined as the process of constructing meaning "by interacting with text through the combination of prior knowledge and previous experience, information in the text, and the stance the reader takes in relationship to the text" (Pardo, 2004, p. 272). Although most authors have worked with comprehension linked only with 
the reading skill, many have studied connections between reading and listening that link both linguistic processes and their roles in developing comprehension (Gough \& Tunmer, 1986; Hogan, Adlof, $\&$ Alonzo, 2014; Uppstad $\varepsilon$ Solheim, 2011). These investigations have led to proposals that offer captivating links between the skills and comprehension.

A classical model that accounts for this connection is the simple view of reading (SVR) model (Gough \& Tunmer, 1986). This model asserts that reading comprehension is directly related to a person's word recognition and listening comprehension abilities. Further research has elaborated on this asserting that listening comprehension is a dominating influence on reading comprehension beginning elementary education (Hogan, Adlof, \& Alonzo, 2014). Furthermore, although the SVR model may not be considered appropriate as a resource for informing teachers' methodological decisions (Uppstad \& Solheim, 2011), it still accounts today for the importance of listening as part of the development of higherorder thinking skills that come from comprehension even when compared to more current alternative theoretical models. In this light, it may be stated that the main difference between reading and listening in terms of comprehension is not the cognitive process itself but the nature of the input. Some of these factors may be the speakers' accents, rate of the delivery, possible environmental noise, and the ephemeral nature of listening (Buck, 2001).

Concerned about dealing with the concept of difficulty in listening tasks, Lund (1990) created a taxonomy that attempted to overcome this challenge. In this taxonomy, the researcher assumed listening to be function-oriented; therefore, there were limited purposes that listening could serve in the real world: identification of linguistic features, orientation (determining essential facts), main idea comprehension, detail comprehension (specific information), full comprehension (distinguishing the whole text function from specific strategies used at different moments of the message), and replication (reproducing the message). Even though this effort is valuable and reflects the relevance of scaffolding comprehension, it has at least two weaknesses.
First, it does not seem to recognize the importance of listeners taking a stance regarding the text in a way in which they can connect the information presented with their own prior knowledge and views. Furthermore, listeners' responses seem to be equated with the format of the task, for example, the taxonomy considers if a full comprehension activity should ask the listener to select an alternative or create an outline about it.

Similarly, Day and Park (2005) highlight six different types of comprehension that teachers should be aware of when designing activities that aim at developing comprehension: literal comprehension, reorganizing, inference, prediction, evaluation, and personal response. In contrast with Lund's (1990), this taxonomy considers the participation of the students' cognitive processes, prior knowledge and interests in the comprehension process. For example, an 'evaluation' listening item would ask the student to assess the quality and relevance of the information presented in the text. Therefore, this taxonomy is in line with Pardo's (2004) definition of comprehension as the active process of integrating prior knowledge with the text, which should lead toward taking a position on it. Even though this taxonomy was prepared for analyzing reading tasks, the similarities with listening tasks are evident; in fact, the classification is akin to others that have been designed for listening such as Lund's (1990). Day and Park's (2005) taxonomy for comprehension types will be presented in terms of listening comprehension.

a) Literal comprehension: This refers to the understanding of the "surface meaning of the text” (Day \& Park, 2005, p. 62). For example, questions that guide the student to notice information explicitly stated in the recording, such as a date, a name, or any other piece of explicit information.

b) Reorganizing: This type of question helps students go beyond the identification of isolated words or phrases, by requiring the hearer to make connections among propositions. If the question leads students to put together two different pieces of explicit information to gain additional understanding, the teacher would be working with this type of comprehension. 
c) Inference: This type of comprehension goes beyond literal understanding. It involves students "combining their literal understanding of the text with their own knowledge and intuitions" (Day \& Park, 2005, p. 63). Researchers have usually classified inferences into two different types: local and global (Graesser, Wiemer-Hastings, \& Wiemer-Hastings, 2001; McKoon \& Ratcliff, 1992; Smith \& Hancox, 2000). Local inferences refer to the process carried out at sentence level while global inferences are used to explain the process of creating mental representations related to overarching ideas about general themes or morals, among other intentions underlying the text.

d) Prediction: Although one might associate this with pre-listening questions used to activate schemata to ease the listening comprehension process, this particular type of prediction alludes to questions asked after listening to the audio. For instance, it might involve the students in a creative process in which they are supposed to imagine what could happen next in the story based on what they have heard.

e) Evaluation: This type of comprehension points to the students' cognitive capacity of assessing how useful the text is based on criteria usually established by the teacher. For example, how representative the aural text is of a particular genre or how relevant the information provided in a talk was.

f) Personal response: This stage involves a creative response from the students that moves them to interact with the text and get involved with it especially in terms of the topic. A question such as what aspects did you find interesting about the video? would foster this type of comprehension, which is necessary so that the students engage with the material in an active and meaningful manner.

This taxonomy emphasizes two important facts about comprehension. First of all, there are different types of comprehension. It makes explicit that a literal comprehension task is cognitively less demanding than a task that aims at students making inferences. As a result, the taxonomy highlights the scaffolding process as essential for developing comprehension. In fact, Day and Park (2005) state that "effective teachers and teachers in more effective schools are frequently observed asking higher level questions, questions that go beyond a literal understanding of a text" (pp. 64-65). Secondly, Day and Park's proposal asserts that the tasks are just a means to an end, which is meaningful communication. Consequently, the tasks in textbooks or created by teachers should aim at heightening the active nature of the receptive skills "regardless of the level of comprehension or the form of the question, teachers and materials developers need to make sure that questions are used to help students interact with the text" (Day $\mathcal{E}$ Park, 2005, p. 67).

It is important to note that there are different tasks to assess comprehension beyond simply comprehension questions. Although simple formats work better to assess a particular type of comprehension, such as true or false activities for literal comprehension, there are no formats that are exclusively used with a specific type. The same true or false activity might be used to work on making inference or conclusions, for example. Therefore, when analyzing types of comprehension developed in a textbook, researchers should not find themselves analyzing only open-ended questions, but all tasks that attempt to help students develop their listening comprehension. After this analysis, one should be able to notice the underlying progression, which makes the scaffolding process evident, thus, highlighting that listening comprehension is developed in depth throughout the year.

\section{Textbooks and the EFL Classroom}

For the majority of students, the textbook used in their EFL lessons is either the sole or main source of linguistic input (Kim \& Hall, 2002; Meurant, 2010). Probably due to this fundamental role, the importance of textbooks has been a controversial matter. On the one hand, some EFL experts have argued that this material lacks flexibility and does not offer opportunities to promote reflection from the teacher (Litz, 2005). Additionally, investigators have complained about the lack of authentic material and the overall inadequacy of how language is presented (Grant E Starks, 2001) as well as the surface level with which they deal with cultural and gender representations (Bahman \& Rahimi, 2010; Gómez- 
Rodríguez, 2015). On the other hand, researchers have stated that some of these problems have been overcome. Demir and Yavuz (2017), for example, claim that in the coursebook series Yes You Can, there were no indications of gender inequality, so the book could be a positive source of input regarding gender representations. Similarly, other authors have asserted that ELT textbooks are at the core of ELT, and that they are beneficial for students' progress and engagement (Cunningsworth, 1995; Sheldon, 1988). This disagreement has led to varied research on the role textbooks play in the EFL classroom.

Researchers have analyzed textbooks from myriad points of view. Among these, two main trends seem to emerge in relation to comprehension: the authenticity of the language and tasks used (Flowerdew \& Miller, 1997; Ghaderpanahi, 2012) and the development of cognitive skills (GökhanUlum, 2016). Concerning the first issue, researchers have pointed out that the input provided for the students tends to differ from language students would be exposed to in the real world (Flowerdew $\mathcal{E}$ Miller, 1997) and that receiving authentic input could improve students' development of the listening skill. In line with this idea, Ghaderpanahi (2012) showed that students who worked with a textbook that included authentic aural texts significantly improved their listening ability during a semester. Therefore, as long as teachers assumed the responsibility of modeling strategies and offering feedback, students should be able to face this type of input, which should bring about significant benefits. Unfortunately, this study did not offer a clear explanation of how comprehension was operationalized.

Regarding the second concern, Gökhan-Ulum (2016) has recently traced the development of reading comprehension in an EFL textbook using Bloom's Taxonomy. The main finding of this study is that the questions used in reading activities only aimed at lower level cognitive skills. Thus, the textbook was not useful for the development of high-level cognitive skills due to its exclusive focus on factual knowledge and remembering information. In fact, the analysis indicates that the book did not scaffold the cognitive development of the students. Although this study outlines the relevance of paying attention to the cognitive development of the students, the taxonomy used is not the most appropriate instrument considering that Bloom himself stated that "ideally each major field should have its own taxonomy of objectives in its own language-more detailed, closer to the special language and thinking of its experts" (Anderson \& Krathworhl, 2001, p. xxviii). For this reason, a taxonomy such as Day and Park's (2005), which has been created for EFL in particular, should be more effective for the task of evaluating the activities in a textbook. The present study sought to use this taxonomy to analyze the types of comprehension in relation to listening developed in the textbook Global English.

\section{Methodology}

This investigation follows Stradling's framework for textbook analysis (Nicholls, 2003). Stradling's proposal aims at identifying weaknesses in a textbook so as to supplement it based on the educational context in which it is being used. His analytical framework consists of four categories: content (the coverage when contrasted with the curriculum), pedagogical value (whether it considers students' prior knowledge, or whether it focuses only on memorization or skills development, etc.), intrinsic quality (if there is author bias or reductionism), and extrinsic factors (price, marketing strategies, etc.). The present research focuses specifically on the pedagogical value dimension since it allows the investigation to account for the development of comprehension. In this light, two main trends of textbook analysis attempt to account for the pedagogical value of a textbook. These include the focus on creating criteria to select appropriate textbooks, which could be considered prospective (Meurant, 2010; Rahimpour \& Hashemi, 2011). The other option is the analysis and evaluation of the textbooks used in schools and universities, usually labeled as retrospective (Aghazadeh, 2015; Alemi E Sadehvandi, 2012; Kirkgöz, 2009; Sidek, 2012). This study is in line with the retrospective trend since it analyzes a textbook that is already being used with $11^{\text {th }}$ graders in most public and subsidized schools in Chile.

As for the retrospective analysis and evaluation of textbooks, researchers have taken two different 
directions. The first consists of gathering the perceptions of people involved in the use of the materials (Alemi \& Sadehvandi, 2012; Mohammadi E Abdi, 2012; Tok, 2010) through tools such as rating scales and questionnaires to later analyze the results using descriptive statistics. On the other hand, the other trend involves examining the nature of the contents included in the textbooks considering factors such as the difficulty of the textbook (Nozawa, 2010; Sidek, 2012). This investigation follows this second line of research. Therefore, it can be considered a descriptive quantitative study that aimed at determining the representativeness and distribution of the types of comprehension developed in the listening activities of the analyzed textbook.

The textbook chosen for this analysis is Global English. This textbook is provided by the Chilean Ministry of Education to all $11^{\text {th }}$ graders attending subsidized and public schools across the country. The reason why Global English was selected for the analysis is that it plays a crucial role in the national curriculum. In fact, Chilean students in $11^{\text {th }}$ grade are expected to sit for the only national standardized test of English, SIMCE (MINEDUC, 2012). In this test, students should achieve a B1 level of English according to the Common European Framework of Reference for Languages (Council of Europe, 2001). Therefore, the textbook should be coherent with the premise of developing comprehension beyond the surface level.

For the analysis of the listening tasks, Day and Park's (2005) taxonomy was used as the theoretical framework to define the construct of listening comprehension. Based on this proposal, a checklist that included the operational definition for each type of comprehension was created. Four different experts in EFL teaching, who were trained in its use, applied this instrument to analyze the listening activities in the textbook Global English. As recommended in Grant and Davis (1997), all the experts were chosen based on their academic expertise and their experience teaching. The number of experts, although at the low end, exceeds the minimum expected (Rubio, Berg-Weger, Tebb, Lee, E Rauch, 2003) and is similar to what has been utilized in other studies in the field (Osman,
Tuan Soh, E Mohamad Arsad, 2010; Sahari, Abdul, Selamat, \& Yunus, 2009).

One week after a training session, the selected experts were sent a document containing all 91 activities identified in the while you listen sections of the textbook. This decision was made based on the fact that before you listen and after you listen sections would include at times activities that were not related to listening comprehension itself. For example, most before-you-listen sections are used to activate prior knowledge or to introduce vocabulary (Figure 1). The experts proceeded to analyze independently each of the listening activities using the checklist and sent the results of their analysis back within a week. Out of the 91 activities, there was a total agreement in the classification of 84 of them (92.3\%). To solve disagreements, a focus group with the same educators was formed later. The focus group exchanged views until agreeing on the classification of the pending questions.

\section{BEFORE YOU LISTEN}

Answer and discuss these questions in your group.

a. Have you ever applied for a job? What type? Did you get it?

b. What's the best place to look for jobs?

Figure 1. Before you listen activity.

\section{Findings and Discussion}

The textbook for $11^{\text {th }}$ graders consists of five thematic units. Each of them is structured in the following manner:

- Learning objectives for the skills of reading, listening, writing, and speaking.

- Getting Ready for the Unit: This section introduces the topic through discussions about pictures and situations followed by a languageoriented recap.

- Reading section: This section includes exercises for pre-, while-, and post-reading activities accompanied by reading strategy tips and useful expressions for the while- or post-reading tasks. This section ends with an application section in 
which the students use the language learned in a writing activity.

- Listening section: This section follows the same structure as the previous one but ends with a speaking task, such as a role-play.

- Consolidation Activities: This section includes grammar, vocabulary, and reading activities that reinforce the learning objectives of the unit.

- Test your Knowledge and Self-Assessment: First, the test your knowledge section consists of five scored sub-sections with its corresponding activities: reading, listening, language, speaking, and writing. Then, a self-evaluation section allows students to check what the obtained score means.

As it can be noticed, the listening section is present in every unit divided in its corresponding three phases: before-you-listen, while-you-listen, and after-you-listen. Listening tasks are supposed to develop students' cognitive skills and prepare them to become active listeners (Lund, 1990; Vandergrift, 2007). Table 1 shows the frequency (F) of questions in any form (multiple-choice, open-ended, etc.) related to each type of comprehension. Moreover, it presents in percentages (\%) how representative that particular type is of the total amount of questions in the unit.

Table 1 shows a clear lack of variety in terms of comprehension and the lack of scaffolding towards a goal. Regarding the type of comprehension of the questions, it is noticeable that most questions concentrate on literal comprehension. This ranges from $69.7 \%$ in Unit 5 to $100 \%$ in Unit 4. Reorganizing appears to be the only other type of comprehension pursued with relative consistency. In spite of this, its representativeness is far from literal comprehension. Personal responses are only present in Unit 2 and in a very low percentage. Finally, there is no demand for the students to infer, predict, or evaluate the information of the audios.

Two findings can be inferred from the previous table. First, the comprehension dimension of the listening skill seems to be reduced to the identification of words and sentences explicitly stated during the recording. This is not in line with what is suggested by experts who emphasize the importance of interacting with the information and moving away from specific answers that come from basic cognitive processes (Day \& Park, 2005; Lund, 1990; Vandergrift, 2007). In fact, there is a clear lack of progression in terms of complexity at a cognitive level. Even though there might be an increasing difficulty in factors such as rate of delivery or the length of the recording, the type of comprehension being developed does not vary significantly as it can be appreciated in Figures 2 and 3 which display activities from the first and last units respectively.

Table 1. Types of comprehension

\begin{tabular}{ccccccccccc}
\hline \multirow{2}{*}{ Types of comprehension } & \multicolumn{3}{c}{ Unit 1 } & \multicolumn{2}{c}{ Unit 2 } & \multicolumn{2}{c}{ Unit 3 } & \multicolumn{2}{c}{ Unit 4 } & \multicolumn{1}{c}{ Unit 5} \\
\cline { 2 - 10 } & $\mathbf{F}$ & $\mathbf{P}$ & $\mathbf{F}$ & $\mathbf{P}$ & $\mathbf{F}$ & $\mathbf{P}$ & $\mathbf{F}$ & $\mathbf{P}$ & $\mathbf{F}$ & $\mathbf{P}$ \\
\hline Literal comprehension & 11 & 91.7 & 11 & 84.6 & 15 & 83.3 & 15 & 100 & 23 & 69.7 \\
Reorganizing & 1 & 8.3 & 0 & 0 & 3 & 16.7 & 0 & 0 & 10 & 30.3 \\
Inference & 0 & 0 & 0 & 0 & 0 & 0 & 0 & 0 & 0 & 0 \\
Prediction & 0 & 0 & 0 & 0 & 0 & 0 & 0 & 0 & 0 & 0 \\
Evaluation & 0 & 0 & 0 & 0 & 0 & 0 & 0 & 0 & 0 & 0 \\
Personal response & 0 & 0 & 2 & 15.4 & 0 & 0 & 0 & 0 & 0 & 0 \\
Total & 12 & 100 & 13 & 100 & 18 & 100 & 15 & 100 & 33 & 100 \\
\hline
\end{tabular}


7 (12 Listen again and circle the word you hear.
a. If it happens to $m e /$ you, it can happen to anyone/everyone.
b. If we stay at home/school, I will not meet anyone else today/ tonight.
c. After/As I hung up, I looked down the hall/stairs.

Figure 2. Listening comprehension activity - unit 1

\section{2 . 46 Listen to the first part of the interview again. Fill in the blanks in these sentences with ONE word.}
a. Can you tell me a bit about yourself?
b. Why do you want to jobs?
c. I have no
d. And it's been very difficult to get to work on
e. I speak fluent and
f. I've been travelling with groups of tourists for at least two

Figure 3. Listening comprehension activity - unit 5

Figure 2 shows a discrimination task in which students are supposed to circle the word they hear in the recording. Similarly, in the activity shown in Figure 3, students should complete the sentence with the same word they hear in the recording. Regarding types of comprehension, both tasks aim at the same level: literal comprehension. Even though there are different types of tasks in the text, there does not seem to exist much progression that prompts students to go from decoding to interpreting, evaluating, and commenting on the information they are presented with. From a teaching perspective, this weakness limits the possibilities students have to interact actively with the aural texts, so it may prove detrimental to the students as language learners and on their performance in standardized tests, such as SIMCE.

Considering the overall development of the students as language learners, this problem is an urgent matter considering students in $11^{\text {th }}$ grade are about to graduate and they need the linguistics skills that will allow them to develop effectively in the real world. In this sense, being able to listen to share information, organize ideas, and evaluate what they hear becomes relevant (Alismail \& McGuire, 2015). Moreover, if students are granted the possibility to perform as active listeners, the progress developing this skill can be greater and the whole learning experience more motivating (Muniandy, 2012). Developing comprehension through scaffolding might help students obtain higher scores in standardized tests, such as SIMCE.

In sum, the importance of quality textbooks in EFL contexts is clear. For example, Flowerdew and Miller (1997) have stated that the language included in this type of material is usually different from that used in the real world, which seems to affect the comprehension of academic lectures. 
Likewise, other researchers have pointed out that the spoken texts used are usually completely scripted, an option that may result in students not developing the capacity to deal with real-world spoken language (Moradi, 2013). In a similar way, the present study has shed light on another weakness: the lack of attention to the scaffolding process in comprehension, which forces students to get used to understanding listening as a passive skill oriented towards the identification of specific words and phrases, very much in line with Gökhan-Ulum's (2016) findings about reading comprehension.

\section{Conclusions}

The analysis shows that there seems to be a lack of awareness in the textbook about the importance of scaffolding in listening comprehension considering that it only promotes a certain type of comprehension while ignoring others. The textbook focuses only on literal comprehension, in other words, identifying specific information such as a name, a date, or a problem. Although the development of comprehension at a literal level is relevant, it is also important that students develop deeper levels of comprehension so that they can become critical thinkers and active listeners. Helping students interact with texts can lead to students understanding listening as an active process of not only decoding information but also of organizing, assessing, and responding to it. Additionally, this would be coherent with the way in which listening models account for the listening process.

It is important not to see the results of this analysis as negative. Instead, they can be understood as an opportunity for teachers to come up with appropriate complementary material or measures to accompany their students' learning process. Additionally, this study may help editors take into consideration two important overlooked factors: scaffolding cognitive processes associated with comprehension and creating tasks that aim at developing different types of comprehension that will help the students become critical thinkers and active listeners. By addressing the development of listening comprehension in the material provided by the Chilean Ministry of Education, there may be more possibilities for students from publically funded schools to achieve the expected levels in the SIMCE.

It would be pertinent for future studies to do similar research on the development of the reading comprehension skill. Investigating this would help revise if the concept of comprehension is equally fuzzy and unelaborated as part of the construct of the reading skill as it is in the case of listening. Moreover, investigating the actual practices of EFL teachers in Chile is important. By researching what teachers do in the classroom, one may state with more precision how negative the effects of the textbook are on the students. In other words, if teachers are modifying the activities in the textbook to develop deeper levels of comprehension, the weaknesses found in this research could be considered less worrisome.

To sum up, textbooks are sources on which teachers frequently rely. In a hectic world, having this material may mean a huge relief for the teacher. Nevertheless, this material does not comply with current listening models proposed by experts such as that of Edwards (2007) and Geranpayeh and Taylor (2013). Consequently, teachers must be both aware and critical of the textbooks they are expected to work with. Knowing that there are weaknesses in the material and, specifically, the nature of these weaknesses, is of fundamental relevance for teachers. Teachers who use this and similar textbooks can make minor adaptations which can help them be more effective. For instance, teachers could create extra questions that aim at developing types of comprehension of a higher complexity, such as inference and evaluation questions without having to ignore the audio and questions they receive from the Ministry of Education. In addition, teachers should always be attentive to the manner in which the textbooks they use conceive of and develop learners' linguistic skills in order to come up with simple and effective solutions, such as the one suggested. By addressing this issue, teachers may supplement this material in a way in which they lead the learner to see the importance of analyzing, evaluating, and commenting on not only written but also aural texts. 


\section{References}

Agencia de Calidad de la Educación. (2013). Resultados SIMCE III medio 2012. Santiago, Chile.

Agencia de Calidad de la Educación. (2015). Síntesis resultados de aprendizaje. Santiago, Chile.

Aghazadeh, Z. (2015). An evaluation of high school English textbooks in Iranian EFL context: Teachers' versus learners' perceptions. Journal of Language Teaching and Research, 6(5), 1115-1124.

https://doi.org/10.17507/jltr.0605.26

Alemi, M., \& Sadehvandi, N. (2012). Textbook evaluation: EFL teachers' perspectives on "pacesetter series." English Language Teaching, 5(7), 64-74.

https://doi.org/10.5539/elt.v5n7p64

Alismail, H., \& McGuire, P. (2015). 21st century standards and curriculum: Current research and practice. Journal of Education and Practice, 6(6), 150-154.

Aloqaili, A. S. (2012). The relationship between reading comprehension and critical thinking: A theoretical study. Journal of King Saud University-Languages and Translation, 24(1), 35-41.

https://doi.org/10.1016/j.jksult.2011.01.001

Anderson, L. W., \& Krathworhl, D. R. (Eds). A taxonomy for learning, teaching, and assessing. New York, NY: Longman.

Bahman, M., \& Rahimi, A. (2010). Gender representation in EFL materials: An analysis of English textbooks of Iranian high schools. Procedia Social and Behavioral Sciences, 9, 273-277.

https://doi.org/10.1016/j.sbspro.2010.12.149

Brown, H. D., \& Abeywickrama, P. (2010). Language assessment: Principles and classroom practices (2nd ed.). New York, NY: Pearson Education.

Buck, G. (2001). Assessing listening. Cambridge: Cambridge University Press.

https://doi.org/10.1017/CBO9780511732959

Cárdenas-Claros, M. S., \& Gruba, P. (2014). Listeners' interactions with help options in CALL. Computer Assisted Language Learning, 27(3), 228-245.

https://doi.org/10.1080/09588221.2012.724425

Council of Europe. (2001). Common European framework of reference for languages: Learning, teaching, assessment. Cambridge, U.K: Press Syndicate of the University of Cambridge.

Cunningsworth, A. (1995). Choosing your coursebook. Oxford: Heinemann.
Danaye, M., Tahriri, A., \& Haghighi, S. (2015). The effect of instructing critical thinking through debate on the EFL learners' reading comprehension. Journal of the Scholarship of Teaching and Learning, 15(4), 21-40.

https://doi.org/10.14434/josotl.v15i4.13191

Day, R. R., E Park, J.-S. (2005). Developing reading comprehension questions. Reading in a Foreign Language, 17(1), 60-73.

Demir, Y., \& Yavuz, M. (2017). Do ELT coursebooks still suffer from gender inequalities? A case study from Turkey. Journal of Language and Linguistic Studies, 13(1), 103-122.

Echeverri, L., \& McNulty, M. (2010). Reading strategies to develop higher thinking skills for reading comprehension. PROFILE: Issues in Teachers' Professional Development, 12(1), 107-123.

Edwards, B. (2007). The future of hearing aid technology. Trends in hearing, 11(1), 31-45.

https://doi.org/10.1177/1084713806298004

Fahim, M., Barjesteh, H., \& Vaseghi, R. (2012). Effects of critical thinking strategy training on male/female EFL learners' reading comprehension. English Language Teaching, 5(1), 140-145.

Flowerdew, J., \& Miller, L. (1997). The teaching of academic listening comprehension and the question of authenticity. English for Specific Purposes, 16, 27-46.

https://doi.org/10.1016/S0889-4906(96)00030-0

Flowerdew, J., \& Miller, J. (2005). Second language listening. Cambridge: Cambridge University Press.

https://doi.org/10.1017/CBO9780511667244

Ghaderpanahi, L. (2012). Using authentic aural materials to develop listening comprehension in the EFL classroom. English Language Teaching, 5(6), 146-153.

https://doi.org/10.5539/elt.v5n6p146

Geranpayeh, A., \& Taylor, L. (Eds.). (2013). Examining listening: Research and practice in assessing second language listening. Cambridge: Cambridge University Press.

Gilakjani, A., \& Ahmadi, M. (2011). A study of factors affecting EFL learners' English listening comprehension and the strategies for improvement. Journal of Language Teaching and research, 2(5), 977-988.

https://doi.org/10.4304/jltr.2.5.977-988

Gökhan-Ulum, O. (2016). A descriptive content analysis of the extent of Bloom's taxonomy in the reading comprehension of the Course Book Q: Skills for Success 4 Reading and Writing. The Qualitative Report, 21(9), 1674-1683. 
Gómez-Rodríguez, L. (2015). The cultural content in EFL textbooks and what teachers need to do about it. Profile, 17(2), 167-187.

https://doi.org/10.15446/profile.v17n2.44272

Gough, P. B., \& Tunmer, W. E. (1986). Decoding, reading, and reading disability. Remedial and special education, 7(1), 6-10.

https://doi.org/10.1177/074193258600700104

Graesser, A. C., Wiemer-Hastings, P., \& Wiemer-Hastings, K. (2001). Constructing inferences and relations during text comprehension. Text Representation: Linguistic and Psycholinguistic Aspects, 2742(901), 249-271.

https://doi.org/10.1075/hcp.8.14gra

Grant, J. S., E Davis, L. L. (1997). Selection and use of content experts for instrument development. Research in Nursing E Health, 20, 269-274.

https://doi.org/10.1002/(SICI)1098-240X(199706) 20:3<269::AID-NUR9>3.0.CO;2-G

Grant, L., E Starks, D. (2001). Screening appropriate teaching materials: Closings from textbooks and television soap operas. International Review of Applied Linguistics in Language Teaching, 39(1), 39-50.

https://doi.org/10.1515/iral.39.1.39

Gruba, P. (2006). Playing the videotext: a media literacy perspective on video-mediated L2 learning. Language Learning E Technology, 10(2), 77-92.

Harmer, J. (2007). The practice of English language teaching (4th ed.). Harlow: Longman.

Hogan, T. P., Adlof, S. M., \& Alonzo, C. N. (2014). On the importance of listening comprehension. International Journal of Speech-Language Pathology, 16(3), 199-207.

https://doi.org/10.3109/17549507.2014.904441

Hosseini, E., Khodaei, F. B., Sarfallah, S., \& Dolatabadi, H. R. (2012). Exploring the relationship between critical thinking, reading comprehension and reading strategies of English university students. World Applied Sciences Journal, 17(10), 1356-1364.

Kim, D., \& Hall, J. K. (2002). The role of an interactive book reading program in the development of second language pragmatic competence. The Modern Language Journal, 86, 332-348.

https://doi.org/10.1111/1540-4781.00153

Kirkgöz, Y. (2009). Evaluating the English textbooks for young learners of English at Turkish primary education. Procedia: Social and Behavioral Sciences, 1(1), 79-83.

https://doi.org/10.1016/j.sbspro.2009.01.016
Lili, Z. (2015). Influence of anxiety on English listening comprehension: An investigation based on the freshmen of English majors. Studies in Literature and Language, 11(6), 40-47.

Litz, D. (2005).Textbook evaluation and ELT management: A South Korean case study. Thesis retrieved from <https://www.asian-efl-journal.com/ Litz_thesis.pdf $>$

Lund, R. (1990). A taxonomy for teaching second language listening. Foreign Language Annals, 23(2), 105-115.

https://doi.org/10.1111/j.1944-9720.1990.tb00348.x

Lynch, T. (2009). Teaching second language listening. Oxford: Oxford University Press.

McKoon, G., \& Ratcliff, R. (1992). Inference during reading. Psychological Review, 99(3), 440-466.

https://doi.org/10.1037/0033-295X.99.3.440

Meurant, R. C. (2010). EFL/ESL textbook selection in Korea and East Asia: Relevant issues and literature review relevant considerations for the choice of a textbook series for native English teacher EFL programs in East Asia. UCMA 2010: The 2010 International Conference on Ubiquitous Computing and Multimedia Applications, 89-102.

MINEDUC. (2012). SIMCE: Orientaciones para docentes prueba de inglés 3ro medio. Santiago: MINEDUC.

Mohammadi, M., E Abdi, H. (2014). Textbook evaluation: A case study. Procedia: Social and Behavioral Sciences, 98(1994), 1148-1155.

Moradi, K. (2013). The impact of listening strategy instruction on academic lecture comprehension: A case of Iranian EFL learners. Procedia: Social and Behavioral Sciences, 70, 406-416.

https://doi.org/10.1016/j.sbspro.2013.01.078

Muniandy, J. (2012). Teaching and learning constructive listening skills: A study. E-Bangi, 7(1), 165-176.

Nicholls, J. (2003). Methods in school textbook research. International Journal of Historical Learning, Teaching and Research, 3(2), 11-26.

Nozawa, Y. (2010). An analysis of the use of modal verbs in EFL textbooks in terms of politeness strategy of English. Waseda University Repository.

Osman, K., Tuan Soh, T. M., \& Arsad, N. (2010). Development and validation of Malaysian 21st century skills instrument (M-21CSI) for science students. Procedia Social and Behavioral Sciences, 9, 599-603.

https://doi.org/10.1016/j.sbspro.2010.12.204 
Pardo, L. S. (2004). What every teacher needs to know about comprehension. Reading Teacher, 58(3), 272-280.

Rahimpour, M., E Hashemi, R. (2011). Textbook selection and evaluation in EFL context. World Journal of Education, 1(2), 62-68.

https://doi.org/10.5430/wje.v1n2p62

Rost, M. (2011). Teaching and researching listening (2nd ed). Harlow, England: Longman.

Rost, M., E Wilson, J. J. (2013). Active listening. Harlow: Pearson Education.

Rubio, D.M., Berg-Weger, M., Tebb, S.S., Lee, E.S., $\varepsilon$ Rauch, S. (2003). Objectifying content validity: Conducting a content validity study in social work research. Social Work Research, 27, 94-104.

https://doi.org/10.1093/swr/27.2.94

Sahari, N., Abdul, A.A., Selamat, H., \& Yunus, M. (2009). Development and validation of mathematics courseware usefulness evaluation instrument for teachers. Journal of Applied Sciences, 9, 535-541.

https://doi.org/10.3923/jas.2009.535.541

Sheldon, L. (1988). Evaluating ELT textbooks and materials. ELT Journal, 42(4), 237-246.

https://doi.org/10.1093/elt/42.4.237

Sidek, H. (2012). EFL textbook analysis. Language E Literacy: A Canadian Educational E-Journal, 14(3), 27-45.

https://doi.org/10.20360/G2HP4J
Smith, E., E Hancox, P. (2000). Representation, coherence and inference. Artificial Intelligence Review, 15(4), 295-323.

https://doi.org/10.1023/A:1011092219561

Tok, H. (2010). TEFL textbook evaluation: From teachers' perspectives. Educational Research and Review, 5(9), 508-517.

Uppstad, P. H., \& Solheim, O. J. (2011). Code and comprehension in written language-considering limitations to the simple view of reading. L1 Educational Studies in Language and Literature, 11(1), 159-174.

Vandergrift, L. (2004). Listening to learn or learning to listen? Annual Review of Applied Linguistics, 24, 3-25.

https://doi.org/10.1017/S0267190504000017

Vandergrift, L. (2007). Recent developments in second and foreign language listening comprehension research. Language Teaching, 40(3), 191-210.

https://doi.org/10.1017/S0261444807004338

Xu, F. (2011). Anxiety in EFL listening comprehension. Theory and Practice in Language Studies, 1(12), 1709-1717.

https://doi.org/10.4304/tpls.1.12.1709-1717 